\title{
KONDISI LINGKUNGAN TEMPAT TUMBUH Shorea johorensis Foxw. DI AREAL HPH PT. AYA YAYANG INDONESIA, KALIMANTAN SELATAN
}

(Site Condition of Shorea johorensis Foxw. at HPH PT Aya Yayang Indonesia, South Kalimantan)

\section{$\mathrm{Oleh} / \mathrm{By}$ :}

\section{Sudin Panjaitan'), Reni S. Wahyuningtyas ${ }^{2)}$ dan Rabiatul Adawiyah ${ }^{3)}$}

1) Peneliti Madya pada Balai Penelitian Kehutanan Banjarbaru, Kalimantan Selatan

2) Peneliti Muda pada Balai Penelitian Kehutanan Banjarbaru, Kalimantan Selatan

3) Staf Pengajar pada Fakultas Kehutanan Universitas Lambung Mangkurat, Kalimantan Selatan

\begin{abstract}
The research aims to investigate some site conditions i.e: percentage of light intensity, soil $p H$ and altitude around the Shorea johorensis Foxw. regeneration at HPH of PT Aya Yayang Indonesia. S. johorensis inventory was done at plot of $50 \mathrm{~m} \times 50 \mathrm{~m}$, which divided into 5 replications in $10 \times 50 \mathrm{~m}$. Each replication consists of 5 plots of $10 \mathrm{~m} \times 10 \mathrm{~m}$. Each plot was, divided into smaller sample plots of $10 m \times 10 m, 5 m \times 5$ and $2 m \times 2 m$ for poles, saplings and seedlings observations, respectively. The result showed that seedlings were abundant (about 2,800 seedlings ha-1), but saplings and poles were poor (about 494 saplings ha-1 and about 76 poles ha-1). Light intensity penetrations around the seedlings, saplings and poles were 22\%-30\%, 22\%-31\% and 29\%-36\%, respectively. This difference suggested that canopy closure was near close, so that limited sunlight penetration reach the middle and ground forest layers. This condition is estimated to limit growth of saplings and poles. Soil pH at this location is around 4,18-4,2 or categorized as very acid. At this location S. johorensis found at altitude of $300 \mathrm{~m}$ asl.
\end{abstract}

Key Words : Shorea johorensis, site condition, HPH PT Aya Yayang Indonesia.

\begin{abstract}
ABSTRAK
Penelitian ini bertujuan untuk mengetahui beberapa kondisi lingkungan tempat tumbuh Shorea johorensis Foxw., seperti: persentase intensitas cahaya matahari yang masuk, $\mathrm{pH}$ tanah dan ketinggian tempat di areal HPH PT. Aya Yayang Indonesia (PT. AYI). Inventarisasi permudaan S. johorensis dilakukan pada plot pengamatan berukuran $50 \mathrm{~m}$ x $50 \mathrm{~m}$ yang dibagi menjadi $5 \mathrm{blok} /$ ulangan $(10 \mathrm{~m} \times$ $50 \mathrm{~m})$ dan di dalamnya terdapat 5 petak $(10 \mathrm{~m}$ x $10 \mathrm{~m})$. Pada masing-masing petak dibuat petak-petak yang lebih kecil untuk pengamatan permudaan tingkat tiang $(10 \mathrm{~m} \times 10 \mathrm{~m})$, pancang $(5 \mathrm{~m} \times 5 \mathrm{~m})$ dan semai $(2 \mathrm{~m} \times 2 \mathrm{~m})$. Hasil penelitian menunjukkan bahwa di lokasi pengamatan (PT. AYI), jumlah semai $S$. johorensis cukup banyak yaitu 28 batang ( 2.800 anakan/ha), sedangkan pancang 29 batang (464 ha) dan tiang 19 batang (76 batang/ha) atau tergolong sangat miskin. Intensitas cahaya di sekitar permudaan tingkat semai, pancang dan tiang berturut-turut antara $22 \%-30 \%, 22 \%-31 \%$ dan 29\%-36\%. Perbedaan yang tidak jauh antara intensitas cahaya di sekitar semai, pancang dan tiang menunjukkan bahwa penutupan tajuk bagian atas cukup rapat sehingga sedikit sekali sinar matahari yang masuk, baik pada lapisan tengah sampai lapisan bawah hutan. Kondisi tersebut diduga menjadi penghambat pertumbuhan permudaan $S$. johorensis, yang ditunjukkan jumlah semai yang berlimpah ternyata tidak diimbangi dengan stok permudaan tingkat tiang dan pancang. Diduga keterbatasan intensitas cahaya yang masuk menghambat pertumbuhan pancang dan tiang sehingga menjadi stagnan
\end{abstract}


dan mati. pH tanah di lokasi penelitian berkisar antara 4,18 - 4,2 (sangat asam). Pada kondisi demikian $S$. johorensis masih dapat tumbuh. Permudaan $S$. johorensis pada lokasi penelitian ditemukan pada ketinggian $300 \mathrm{~m}$ dpl.

\section{Kata Kunci : Shorea johorensis, kondisi lingkungan tempat tumbuh, intensitas cahaya, pH tanah, tinggi tempat, HPH PT. Aya Yayang Indonesia.}

\section{PENDAHULUAN}

Shorea johorensis Foxw merupakan salah satu pohon penghasil kayu meranti merah yang cukup komersial di Indonesia serta mempunyai riap yang tinggi (Sukotjo, 2009). Hasil uji jenis di PT. Sari Bumi Kusuma Kalimantan Tengah dan PT. ITCI Kalimantan Timur menunjukkan bahwa $S$. johorensis termasuk salah satu jenis dengan pertumbuhan tercepat selain S. leprosula dan S. parvifolia (Hardiyanto, 2006). Saat ini S. johorensis termasuk dalam salah satu dari 7 jenis target yang menjadi unggulan dalam teknik silvikultur intensif (SILIN) karena mempunyai prospek yang baik untuk dikembangkan dalam hutan tanaman meranti di Indonesia. Shorea johorensis di Kalimantan dikenal dengan nama kenuar, kenuwar, majau, langko, merampu dan pelepak. Sedangkan di Sumatera dikenal dengan nama merkuyong (Sukotjo, 2009). Daerah penyebaran jenis ini meliputi Semenanjung Malaysia, Sumatera dan Kalimantan. Di Sumatera hanya terdapat di pantai timur, mulai dari Sumatera Utara sampai Palembang, sedangkan di Kalimantan terdapat di seluruh pulau (Sukotjo, 2009). Sejak terjadi eksploitasi yang cukup intensif terhadap hutan tropis di Kalimantan, maka jumlah dan keberadaan beberapa jenis Dipterocarpaceae termasuk S. johorensis mulai menurun. Panjaitan et al. (2004), pada hutan bekas tebang pilih, kehadiran beberapa spesies komersial seperti S. leprosula dan $S$. parvifolia cukup banyak tetapi $S$. johorensis sudah mulai jarang dan sedikit sekali ditemukan. Khusus di Kalimantan Selatan, Panjaitan et al. (2004) mengatakan bahwa S. johorensis hanya ditemukan pada tempat-tempat tertentu saja.

Mengingat keberadaan S. johorensis yang mulai menurun, maka upaya budidaya dan pelestariannya harus dilakukan. Selain itu informasi kondisi ekologis tempat tumbuhnya juga penting dipelajari untuk mengetahui mengapa di tempat-tempat tertentu jenis ini hadir sedangkan di tempat lain sulit ditemukan. Beberapa informasi tempat tumbuh $S$. johorensis juga telah diketahui seperti kondisi tanah mempunyai drainase yang baik, tumbuh baik di bawah $600 \mathrm{~m}$ dpl, tekstur tanah lempung berliat (clay loam) dan menyukai tanah yang subur. Selain kondisi ekologis di atas, intensitas cahaya yang masuk, $\mathrm{pH}$ tanah dan ketinggian tempat diduga juga berpengaruh penting terhadap kehadiran dan pertumbuhan permudaan jenis ini. Untuk itu perlu diketahui berapa besar intensitas cahaya yang masuk di sekitar anakan $S$. johorensis pada tingkat semai, pancang dan tiang, juga kondisi $\mathrm{pH}$ tanah dan ketinggian tempat di sekitar permudaannya. Informasi yang diperoleh diharapkan dapat menjadi 
bahan masukan untuk mengembangkan jenis ini sehingga pada akhirnya keberadaan Shorea johorensis dapat dipertahankan.

\section{BAHAN DAN METODE PENELITIAN}

\section{A. Lokasi Penelitian}

Penelitian dilakukan di areal HPH PT. Aya Yayang Indonesia yang terletak di Desa Dambung, Kecamatan Haruai, Kabupaten Tabalong, Propinsi Kalimantan Selatan. Jenis tanah yang berada di sekitar lokasi penelitian secara umum adalah podzolik merah kuning (Ultisol), dengan tingkat kesuburan rendah, rata-rata curah hujan tinggi (2.200 mm/tahun) dengan penyebaran yang bervariasi pada periode bulan basah antara Nopember-Januari dan Februari-April. Topografi lapangan bervariasi dari datar sampai curam dengan kelerengan sekitar $45^{\circ}$.

\section{B. Bahan dan Alat Penelitian}

Bahan penelitian yang digunakan adalah permudaan alam meranti merah (S. johorensis) tingkat semai, pancang dan tiang yang berada dalam plot pengamatan. Alat penelitian yang digunakan adalah lux meter untuk mengukur intensitas cahaya, phiband untuk mengukur diameter batang dan $\mathrm{pH}$ meter untuk mengukur $\mathrm{pH}$ tanah.

\section{Metode Penelitian}

Penelitian dilakukan dengan inventarisasi permudaan alam $S$. johorensis mulai dari tingkat semai, pancang dan tiang pada plot pengamatan berukuran $50 \mathrm{~m}$ x $50 \mathrm{~m}$. Penentuan petak pada areal yang diteliti dilakukan secara purposive sampling yaitu dengan memilih lokasi yang dapat mewakili vegetasi dan lingkungan di sekitarnya. Berdasarkan hasil inventarisasi terdahulu oleh perusahaan diketahui bahwa di lokasi tersebut mempunyai populasi permudaan $S$. johorensis yang cukup banyak sehingga diduga merupakan habitat yang sesuai untuk S. johorensis.

Plot pengamatan berukuran $50 \mathrm{~m}$ x $50 \mathrm{~m}$ tersebut kemudian dibagi lagi menjadi 5 blok berukuran $10 \mathrm{~m}$ x $50 \mathrm{~m}$ sebagai ulangan. Masing-masing blok terdiri atas 5 petak berukuran $10 \mathrm{~m} \times 10 \mathrm{~m}$, sehingga seluruhnya terdapat 25 petak yang masing masing berukuran $10 \mathrm{~m}$ x $10 \mathrm{~m}$. Untuk mengamati kehadiran permudaan $S$. johorensis pada setiap tingkat pertumbuhan mulai dari semai, pancang dan tiang, maka di dalam petak dibuat sistem nested sampling yaitu petak berukuran $10 \mathrm{~m} \times 10 \mathrm{~m}$ untuk pengamatan permudaan tingkat tiang, $5 \mathrm{~m}$ x $5 \mathrm{~m}$ untuk mengamati permudaan tingkat pancang dan $2 \mathrm{~m}$ x 2 m untuk mengamati permudaan tingkat semai. Kriteria yang digunakan untuk klasifikasi tingkat pertumbuhan tersebut adalah berdasarkan Soerianegara dan Indrawan (1978) yaitu :

- semai adalah permudaan yang tingginya $<1,5 \mathrm{~m}$

- pancang adalah permudaan yang tingginya $>1,5 \mathrm{~m}$ sampai $3 \mathrm{~m}$

- tiang adalah permudaan yang tingginya $>3 \mathrm{~m}$ dan mempunyai diameter $<10 \mathrm{~cm}$. 


\section{Pengumpulan Data}

Data yang dikumpulkan meliputi kehadiran permudaan $S$. johorensis tingkat semai, tiang dan pancang, persentase intensitas cahaya matahari yang masuk dan $\mathrm{pH}$ tanah. Pengambilan data intensitas cahaya dilakukan pada pukul 11.00 sampai 13.00 siang karena pada waktu tersebut sudut penyinaran matahari relatif kecil (posisi matahari tegak lurus bumi) sehingga diharapkan sinar matahari yang masuk ke lokasi pengamatan dalam posisi maksimal. Untuk mengukur intensitas cahaya matahari yang masuk dilakukan pada waktu bersamaan antara di lantai hutan (di sekitar $S$. johorensis) dengan di ruang terbuka (kontrol) yang mendapat sinar matahari penuh, sehingga dapat dibandingkan berapa persen sinar matahari yang masuk pada lokasi pengamatan dan di ruang terbuka. Setiap pengamatan diulang sebanyak 3 kali kemudian diambil nilai rata-ratanya (dalam satuan candela). Untuk mengetahui persentase cahaya matahari yang masuk di sekitar permudaan $S$. johorensis maka dilakukan perhitungan sebagai berikut:

$$
\begin{aligned}
& \text { IC }(\%)= \frac{\text { IC Pengamatan }}{\text { IC Kontrol }} \times 100 \% \\
& \text { Dimana : IC (\%) adalah persentase cahaya matahari yang masuk, IC } \\
& \begin{aligned}
\text { pengamatan adalah intensitas cahaya di sekitar S. johorensis } \\
\text { dan IC kontrol adalah intensitas cahaya di tempat terbuka. }
\end{aligned}
\end{aligned}
$$

\section{E. Analisis Data}

Data yang diperoleh selama penelitian diolah dan dianalisis secara diskriptif untuk mendapatkan gambaran keadaan faktor tempat tumbuh pada areal ditemukannya permudaan $S$. johorensis di lokasi tersebut.

\section{HASIL DAN PEMBAHASAN}

\section{A. Hasil}

\section{Kehadiran $S$. johorensis}

Data hasil inventarisasi untuk mengetahui kehadiran permudaan S. johorensis pada 25 petak pengamatan disajikan pada Tabel 1 .

Hasil inventarisasi $S$. johorensis pada 25 petak pengamatan menunjukkan bahwa kehadiran permudaan ini pada tingkat semai dan pancang hampir sama yaitu sebanyak 28 dan 29 batang dengan posisi mengelompok. Sedangkan permudaan $S$. johorensis pada tingkat tiang jauh lebih sedikit yaitu 19 batang dengan kondisi tersebar merata pada masing-masing blok.

Semakin sedikitnya permudaan tingkat tiang dibandingkan tingkat pancang dan semai adalah wajar karena semakin bertambah umur, dari ribuan semai akan tersisa sedikit individu yang mampu bertahan hidup dan terus tumbuh untuk menjadi pohon dewasa. Individu yang mampu bertahan hidup pun lebih tersebar, cenderung tidak tumbuh berdekatan seperti sekumpulan semai (seedling) karena 
telah terjadi persaingan ruang tumbuh dan hara, baik dengan jenis yang sama maupun dengan jenis yang berbeda.

Tabel (Table) 1. Jumlah permudaan S. johorensis dari hasil inventarisasi (Amount of $\mathrm{S}$. johorensis regeneration from the inventory)

\begin{tabular}{|c|c|c|c|}
\hline \multirow{2}{*}{$\begin{array}{c}\text { Blok } \\
\text { (Block) }\end{array}$} & \multicolumn{3}{|c|}{ Jumlah permudaan $S$. johorensis (Amount of $\mathrm{S}$. johorensis regeneration) } \\
\hline & semai (seedlings) & pancang (saplings) & tiang (poles) \\
\hline 1 & 7 & 3 & 5 \\
\hline 2 & 7 & 8 & 2 \\
\hline 3 & 2 & 9 & 4 \\
\hline 4 & 6 & 2 & 5 \\
\hline 5 & 6 & 7 & 3 \\
\hline Jumlah (amount) & 28 & 29 & 19 \\
\hline Kerapatan /plot (density per plot) & 28 anakan $/ 100 \mathrm{~m}^{2}$ & 29 pancang $/ 625 \mathrm{~m}^{2}$ & 19 tiang $/ 2.500 \mathrm{~m}^{2}$ \\
\hline Kerapatan ha $^{-1}($ density per ha $)$ & $2800 /$ ha & $464 / \mathrm{ha}$ & $76 /$ ha \\
\hline
\end{tabular}

\section{Intensitas Cahaya}

Pengamatan intensitas cahaya yang masuk di sekitar permudaan S. johorensis pada lokasi pengamatan disajikan pada Tabel 2.

Tabel (Table) 2. Intensitas cahaya yang masuk di sekitar permudaan Shorea johorensis (Light intensity penetration around $\mathrm{S}$. johorensis regeneration)

\begin{tabular}{|c|c|c|c|c|c|c|c|c|c|}
\hline \multirow{3}{*}{$\begin{array}{l}\text { Tingkat } \\
\text { Pertumbuhan } \\
\text { (Growth } \\
\text { level) }\end{array}$} & \multirow{3}{*}{$\begin{array}{l}\text { Blok } \\
(\text { Block })\end{array}$} & \multicolumn{5}{|c|}{$\begin{array}{c}\text { Intesitas cahaya di sekitar permudaan } \\
\text { (Light intensity around of regeneration ) }\end{array}$} & \multirow{3}{*}{$\begin{array}{l}\text { Jumlah } \\
\text { (Sum) }\end{array}$} & \multirow{3}{*}{$\begin{array}{l}\text { Rata-rata } \\
\text { (Average) }\end{array}$} & \multirow{3}{*}{$\begin{array}{c}\text { Persentase IC } \\
\text { masuk (light } \\
\text { intensity } \\
\text { penetration) } \\
(\%)\end{array}$} \\
\hline & & \multicolumn{5}{|c|}{ Nomer plot (plot number) } & & & \\
\hline & & 1 & 2 & 3 & 4 & 5 & & & \\
\hline & $\mathrm{I}$ & 115,33 & 126,67 & 126,67 & 108,33 & 94,67 & 571,67 & 114,334 & 25,84 \\
\hline & II & 152,33 & 163,67 & 154,33 & 104 & 92 & 666,33 & 133,266 & 30,12 \\
\hline \multirow[t]{6}{*}{ Semai } & III & 120 & 99,67 & 92,67 & 91,67 & 91 & 495,01 & 99,002 & 22,37 \\
\hline & IV & 183 & 119,33 & 221 & 73,33 & 74,67 & 671,33 & 134,266 & 30,34 \\
\hline & $\mathrm{V}$ & 122,67 & 126 & 182,33 & 102 & 182,67 & 715,67 & 143,134 & 32,35 \\
\hline & & & & & & & & & 28,20 \\
\hline & $\mathrm{I}$ & 148,00 & 142,33 & 168,67 & 94,67 & 95,67 & 649,34 & 129,868 & 29,35 \\
\hline & II & 143,33 & 148,00 & 143,00 & 101,67 & 95,67 & 631,67 & 126,334 & 28,55 \\
\hline \multirow[t]{6}{*}{ Pancang } & III & 117 & 105,67 & 88,67 & 99,33 & 95,33 & 506 & 101,2 & 22,87 \\
\hline & IV & 236,33 & 145 & 271 & 100,67 & 83 & 836 & 167,2 & 37,79 \\
\hline & $\mathrm{V}$ & 153,33 & 126 & 215,33 & 101,67 & 99,33 & 695,66 & 139,132 & 31,44 \\
\hline & & & & & & & & & 30,00 \\
\hline & $\mathrm{I}$ & 136,33 & 118,33 & 158,33 & 101,33 & 143,33 & 657,65 & 131,53 & 29,72 \\
\hline & II & 133,33 & 114,33 & 110,67 & 134 & 171,33 & 663,66 & 132,732 & 30,00 \\
\hline \multirow[t]{4}{*}{ Tiang } & III & 161 & 137,67 & 155,67 & 98 & 75,33 & 627,67 & 125,534 & 28,37 \\
\hline & IV & 132,67 & 185,67 & 266,67 & 96,67 & 118 & 799,68 & 159,936 & 36,14 \\
\hline & $\mathrm{V}$ & 166 & 105 & 164,67 & 89,67 & 122 & 647,34 & 129,468 & 29,26 \\
\hline & & & & & & & & & 30,70 \\
\hline
\end{tabular}

Keterangan (Remarks) : Rata-rata intensitas cahaya di tempat terbuka $=442,5$ candela (Average of light intensity at open area $=442,5$ candle)

Hasil pengukuran menunjukkan bahwa rata-rata intensitas cahaya yang masuk di sekitar permudaan tingkat semai adalah sekitar $28,2 \%$, pada tingkat pancang $30 \%$ dan pada tingkat tiang $30,70 \%$. Semakin rendah intensitas cahaya yang masuk menandakan kondisi lingkungan yang semakin tertutup sehingga hanya sedikit cahaya matahari yang dapat menembus ke lantai hutan. Dibandingkan permudaan tingkat pancang dan tiang, maka dapat dikatakan intensitas cahaya yang masuk di sekitar permudaan tingkat semai jauh lebih sedikit. Hal ini dikarenakan permudaan tingkat semai terletak pada strata lapisan tajuk bagian bawah. Pada posisi tersebut, cahaya matahari yang 
menembus kanopi hutan akan tersaring oleh lapisan-lapisan tajuk di atasnya sehingga hanya sedikit yang sampai pada lapisan bawah.

Distribusi permudaan $S$. johorensis tingkat semai, tiang dan pancang pada beberapa kondisi lingkungan berdasarkan persentase intensitas cahaya yang masuk digambarkan sebagai berikut.

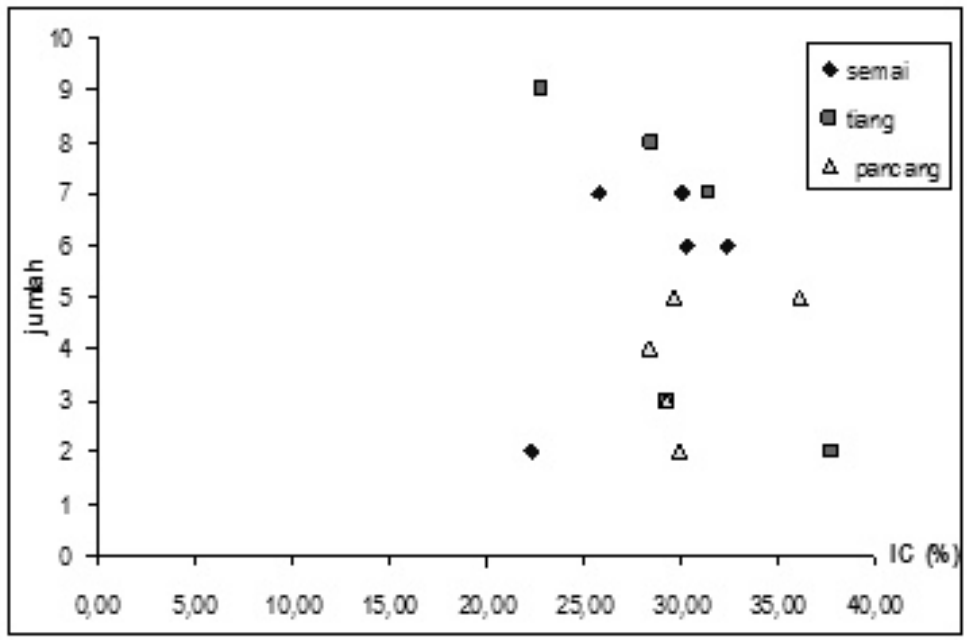

Gambar (Figure)1. Kehadiran permudaan S. johorensis pada tingkat semai, tiang dan pancang pada kondisi lingkungan berdasarkan intensitas cahaya yang masuk (Presence of $\mathrm{S}$. johorensis regeneration at seedling, sapling and poles stage under some light intensity condition)

Gambar 1 menunjukkan bahwa besarnya intensitas cahaya matahari yang masuk di sekitar permudaan S. johorensis umumnya berkisar antara 20\% - 40\%. Di sekitar permudaan tingkat semai, persentase cahaya matahari yang masuk lebih rendah dibandingkan di sekitar permudaan tingkat pancang dan tiang. Namun secara umum sebaran terbanyak permudaan $S$. johorensis baik tingkat semai, tiang dan pancang terdapat pada kondisi intensitas cahaya sebanyak $30 \%$.

\section{3. pH Tanah}

Kondisi $\mathrm{pH}$ tanah di sekitar permudaan S. johorensis pada lokasi pengamatan disajikan pada Tabel 3.

Hasil pengukuran menunjukkan bahwa $\mathrm{pH}$ tanah di sekitar permudaan S. johorensis tingkat semai berkisar antara 3,88 - 4,49 (rata-rata 4,18), pada permudaan tingkat pancang berkisar antara 3,99 - 4,51 (rata-rata 4,20) dan pada permudaan tingkat tiang berkisar antara 4,07-4,37 (rata-rata 4,20). Secara umum $\mathrm{pH}$ tanah di sekitar permudaan S. johorensis dapat dikatakan sangat masam (Olson 1981 dalam Purwowidodo, 2000). 
Tabel (Table) 3. pH tanah di sekitar permudaan S. johorensis (Soil pH around of S. johorensis regeneration)

\begin{tabular}{|c|c|c|c|c|c|c|c|c|}
\hline \multirow{2}{*}{$\begin{array}{l}\text { Tingkat pertumbuhan } \\
\text { (Growth stage) }\end{array}$} & \multirow{2}{*}{$\begin{array}{l}\text { Blok } \\
(\text { Block })\end{array}$} & \multicolumn{5}{|c|}{$\begin{array}{l}\mathrm{pH} \text { tanah pada masing-masing plot } \\
\text { (Soil pH at each plot) }\end{array}$} & \multirow{2}{*}{$\begin{array}{l}\text { Jumlah } \\
\text { (Sum) }\end{array}$} & \multirow{2}{*}{$\begin{array}{c}\mathrm{pH} \text { rata-rata } \\
(\text { Average of } p H)\end{array}$} \\
\hline & & 1 & 2 & 3 & 4 & 5 & & \\
\hline \multirow{6}{*}{ Semai (seedling) } & I & 4,49 & 4,23 & 4,26 & 4,17 & 4,22 & 21,37 & 4,27 \\
\hline & II & 4,10 & 4,15 & 4,21 & 3,99 & 4,11 & 20,56 & 4,11 \\
\hline & III & 4,18 & 4,24 & 4,08 & 4,28 & 4,20 & 20,98 & 4,20 \\
\hline & IV & 4,18 & 4,31 & 4,21 & 3,88 & 4,27 & 20,85 & 4,17 \\
\hline & $\mathrm{V}$ & 4,16 & 4,16 & 4,25 & 4,08 & 4,05 & 20,70 & 4,14 \\
\hline & & & & & & & & 4,18 \\
\hline \multirow{6}{*}{ Pancang (sapling) } & I & 4,12 & 4,28 & 4,15 & 4,11 & 4,03 & 20,69 & 4,14 \\
\hline & II & 4,16 & 3,99 & 4,11 & 4,04 & 4,03 & 20,33 & 4,07 \\
\hline & III & 4,22 & 4,14 & 4,13 & 4,25 & 4,10 & 20,84 & 4,17 \\
\hline & IV & 4,39 & 4,38 & 4,25 & 4,21 & 4,51 & 21,74 & 4,35 \\
\hline & $\mathrm{V}$ & 4,20 & 4,31 & 4,37 & 4,29 & 4,24 & 21,41 & 4,28 \\
\hline & & & & & & & & 4,20 \\
\hline \multirow{6}{*}{ Tiang (pole) } & I & 4,34 & 4,29 & 4,15 & 4,07 & 4,19 & 21,04 & 4,21 \\
\hline & II & 4,12 & 4,14 & 4,22 & 4,17 & 4,07 & 20,72 & 4,14 \\
\hline & III & 4,37 & $-\frac{1,17}{4,22}$ & 4,29 & 4,21 & 4,10 & 21,19 & 4,24 \\
\hline & IV & 4,16 & $-4,20$ & 4,25 & 4,14 & 4,22 & 20,97 & 4,19 \\
\hline & $\mathrm{V}$ & 4,14 & 4,36 & 4,16 & 4,26 & 4,28 & 21,20 & 4,24 \\
\hline & & & & & & & & 4,20 \\
\hline
\end{tabular}

\section{Ketinggian Tempat}

Hasil pengukuran ketinggian tempat lokasi tempat tumbuh permudaan $S$. johorensis disajikan pada Tabel 4 .

Tabel (Table) 4. Ketinggian tempat di sekitar tempat tumbuh permudaan S. johorensis

(Elevation around of $\mathrm{S}$. johorensis regeneration site)

\begin{tabular}{|c|c|c|c|c|c|c|c|c|}
\hline \multirow{2}{*}{$\begin{array}{l}\text { Tingkat pertumbuhan } \\
\text { (Growth stage) }\end{array}$} & \multirow{2}{*}{$\begin{array}{c}\text { Blok } \\
(\text { Block })\end{array}$} & \multicolumn{5}{|c|}{$\begin{array}{l}\text { Tinggi tempat }(\mathrm{m} \text { dpl) pada plot no } \\
\text { (Elevation ( } m \text { above sea level) at plot number) }\end{array}$} & \multirow{2}{*}{$\begin{array}{l}\text { Jumlah } \\
(\text { Sum })\end{array}$} & \multirow{2}{*}{$\begin{array}{l}\text { Rata-rata } \\
\text { (Average) }\end{array}$} \\
\hline & & 1 & 2 & 3 & 4 & 5 & & \\
\hline \multirow{6}{*}{ Semai (seedling) } & I & 329 & 327,33 & 324 & 317,67 & 313,67 & 1611,67 & 322,33 \\
\hline & II & 327,67 & 324 & 318,67 & 315,67 & 310 & 1596,01 & 319,20 \\
\hline & III & 328,67 & 323 & 321 & 318 & 313 & 1603,67 & 320,73 \\
\hline & IV & 328 & 324 & 320 & 313 & 313 & 1598 & 319,60 \\
\hline & V & 328 & 323,67 & 320 & 315 & 312 & 1598,67 & 319,73 \\
\hline & & & & & & & & 320,32 \\
\hline \multirow{6}{*}{ Pancang (sapling) } & I & 329,00 & 326,00 & 321,00 & 316,67 & 311,67 & 1604,34 & 320,87 \\
\hline & II & 328,33 & 325,00 & 319,67 & 316,67 & 310,33 & 1600 & 320,00 \\
\hline & III & 325,67 & 322,33 & 319,67 & 317,33 & 314,33 & 1599,33 & 319,87 \\
\hline & IV & 326,33 & 322 & 316,33 & 314 & 309 & 1587,66 & 317,53 \\
\hline & $\mathrm{V}$ & 327,33 & 322 & 316 & 314,67 & 311,67 & 1591,67 & 318,33 \\
\hline & & & & & & & & 319,32 \\
\hline \multirow{6}{*}{ Tiang (pole) } & I & 328,33 & 324 & 319 & 316 & 310,67 & 1598 & 319,60 \\
\hline & II & 329,33 & 326,33 & 323 & 317,33 & 313,33 & 1609,32 & 321,86 \\
\hline & III & 327 & 321,33 & 319,33 & 316,33 & 312,67 & 1596,66 & 319,33 \\
\hline & IV & 326,67 & 321 & 317 & 315,33 & 312 & 1592 & 318,40 \\
\hline & V & 325,33 & 321,67 & 316,66 & 312,67 & 311 & 1587,33 & 317,47 \\
\hline & & & & & & & & 319,33 \\
\hline
\end{tabular}

Ketinggian tempat pada lokasi tempat tumbuh permudaan $S$. johorensis berkisar antara 309-329,33 m dpl. Antara permudaan tingkat semai, pancang dan tiang menunjukkan ketinggian tempat tumbuh yang tidak terlalu jauh berbeda, yaitu masing-masing pada kisaran $320,32 \mathrm{~m}$ dpl, $319,32 \mathrm{~m}$ dpl dan 319,33 m dpl. 


\section{B. Pembahasan}

Hasil inventarisasi pada plot pengamatan seluas $2.500 \mathrm{~m}^{2}$ di areal HPH PT. Aya Yayang Indonesia (PT. AYI) menunjukkan bahwa permudaan $S$. johorensis tingkat semai ditemukan sebanyak 28 semai ( \pm 2.800 semai/ha), 29 pancang ( \pm 464 pancang/ha) dan 19 tingkat tiang $( \pm 76$ tiang/ha).

Apabila lingkungan sesuai, secara alami jenis Shorea sangat mudah beregenerasi. Di hutan alam, permudaan tingkat semai umumnya berjumlah lebih dari 1.000 anakan/ha, sedangkan tingkat pancang jumlahnya bervariasi dari kriteria banyak ( $>240$ anakan/ha) sampai miskin ( $<240$ anakan/ha). Dari hasil penelitian menunjukkan bahwa tingkat semai permudaan $S$. johorensis tergolong cukup banyak, tetapi untuk tingkat pancang dan tiang tergolong sangat miskin. Hal ini diduga karena kondisi lingkungan di lokasi penelitian kurang mendukung bagi pertumbuhan permudaan S. johorensis sehingga pertumbuhan permudaan tingkat pancang menjadi terhambat (stagnan) dan kemudian mati.

Apabila dilihat dari sejarah lokasi pengamatan, areal tersebut merupakan hutan bekas tebang pilih sekitar 10 tahun lalu dengan kondisi permudaan cukup rapat. Secara umum pohon komersial yang tumbuh juga masih beragam seperti: meranti (Shorea sp.), keruing (Dipterocarpus sp.), nyatoh (Palaquium sp.), kapur (Dryobalanops sp.), merijang (Sindora sp.), ulin (Eusideroxylon zwageri), bangkirai (Shorea laevis), balau (S. elliptica) dan biwan (Endertia spectabilis). Dibandingkan dengan jenis tersebut, permudaan $S$. johorensis pada tingkat pancang tergolong tidak banyak.

Secara umum, intensitas cahaya yang masuk di sekitar tempat tumbuh permudaan $S$. johorensis sekitar 30\%. Di antara permudaan tingkat semai, pancang dan tiang intensitas cahaya yang masuk hampir seimbang yaitu berturut-turut sebanyak $22 \%-30 \%$ pada tingkat semai, $22 \%-31 \%$ pada tingkat pancang dan 29\% - 36\% pada tingkat tiang. Perbedaan intensitas cahaya yang tidak jauh antara tingkat semai, pancang dan tiang diduga disebabkan oleh tutupan tajuk pada lapisan atas yang cukup rapat sehingga sedikit celah sinar matahari dapat masuk baik pada strata tengah hingga strata bawah.

Menurut Longman dan Jenik (1974), intensitas cahaya yang masuk ke hutan tropis secara horizontal sangat bervariasi tergantung kondisi cuaca, penutupan tajuk dan sudut kedatangan sinar matahari. Pada kondisi tajuk yang tertutup, intensitas cahaya yang masuk pada lapisan di bawahnya dapat berkurang sekitar 25\%. Intensitas cahaya yang masuk akan semakin rendah pada lapisan bawah. Rata-rata intensitas cahaya relatif yang masuk ke lantai hutan di hutan tropis Suriname hanya sekitar 2\%-5\%, sedangkan hutan tropis (virgin forest) di Indonesia jauh lebih rendah yaitu 0,2\%-0,7\% (Longman dan Jenik, 1974).

Beberapa Dipterocarpaceae seperti Parashorea dan Shorea (khususnya meranti merah) memang tergolong dalam light timber hardwoods yaitu cepat merespon keberadaan cahaya yang masuk. $S$. parvifolia adalah strongly light-demanding pada golongan meranti merah (Whitmore, 1975). Beberapa hasil penelitian lain juga menunjukkan bahwa toleransi kebutuhan cahaya beberapa meranti merah cukup beragam. Hasil penelitian Wahyuningsih (1996) menunjukkan bahwa pertumbuhan tinggi anakan S. leprosula optimum pada intensitas cahaya sebesar 13\%-50\% dan kandungan air tanah 
$60 \%$, sedangkan pertumbuhan diameternya lebih cepat pada tempat dengan intensitas cayaha $=50 \%$ dan kandungan air 60\%. Sedangkan Effendi (1987) menyatakan bahwa jenis S. leprosula dan $S$. acuminatissima di hutan tropis Kalimantan Selatan pertumbuhan meningginya maksimum dicapai pada intensitas cahaya $=50 \%$, sedangkan pertumbuhan diameter maksimum dicapai pada intensitas cahaya $=75 \%$. Titik kompensasi cahaya terletak pada kisaran 350-400 kandela dengan kecenderungan meningkat karena naiknya intensitas cahaya. Laju pertumbuhan kedua jenis yang diteliti terjadi pada kisaran intensitas cahaya 50\%-70\% cahaya penuh.

Karena $S$. johorensis juga termasuk dalam golongan meranti merah dan mempunyai karakter light demanding, maka dalam kondisi lingkungan yang tertutup seperti di areal penelitian, pembukaan tajuk sangat diperlukan untuk menstimulir pertumbuhan anakan $S$. johorensis sejak dari tingkat pancang (tinggi anakan $>1,5 \mathrm{~m}$ ) agar dapat tumbuh cepat dengan riap optimal. Hasil penelitian Zulfahani (1987) juga menunjukkan bahwa semai S. johorensis memerlukan naungan untuk perkembangannya, namun semakin dewasa jenis ini mulai menunjukkan penurunan toleransi. Sukotjo (2009) bahkan menyatakan bahwa $S$. johorensis sudah memerlukan cahaya cukup banyak sejak dari semai. Ini dibuktikan dari hasil uji spesies bahwa semai $S$. johorensis yang tumbuh di blok yang ternaung pertumbuhan diameternya lambat, sedangkan di blok relatif terbuka rerata diameternya tumbuh sangat cepat.

Kondisi tanah di sekitar tempat tumbuh permudaan $S$. johorensis secara umum tergolong sangat asam (Olson, 1981 dalam Purwowidodo, 2000). Padahal S. johorensis umumnya tumbuh di tempat yang subur dengan tipe tanah clay-loam (lempung liat) (Sukotjo, 2009). Menurut Longman dan Jenik (1974) pada daerah dengan curah hujan tinggi seperti di Kalimantan, $\mathrm{pH}$ tanahnya memang cenderung sangat asam bahkan sering $<4$, sedangkan nisbah $\mathrm{C} / \mathrm{N}$ umumnya tinggi. Tanah dengan mineral kaolinit seperti pada lokasi penelitian umumnya juga mengandung unsur Fe dan Al tinggi, serta kapasitas tukar kation yang rendah kecuali pada lapisan humus.

Walaupun secara umum unsur hara tersedia dan dapat diserap tanaman pada kondisi $\mathrm{pH}$ tanah yang netral (Hardjowigeno, 1995), tetapi hasil penelitian menunjukkan bahwa kondisi $\mathrm{pH}$ tanah di lokasi penelitian yang sangat asam masih memungkinkan $S$. johorensis dan beberapa jenis komersial lainnya tumbuh dengan baik. Adanya simbiosis mutualisme antara mikoriza pada sistem perakaran Dipterocarpaceae diduga sangat berperan dalam membantu penyerapan unsur hara khususnya unsur $\mathrm{P}$ dari dalam tanah sehingga masalah kondisi tempat tumbuh yang kurang subur dapat diatasi.

Secara umum $S$. johorensis pada lokasi penelitian berada pada ketinggian sekitar $300 \mathrm{~m}$ dpl. Hal ini sesuai dengan yang dikemukakan Bratawinata, (2001) bahwa S. johorensis termasuk tipe vegetasi dataran rendah hutan Dipterocarpaceae yang umumnya tumbuh pada kisaran ketinggian 300-800 m dpl. Sukotjo (2009) juga menyatakan bahwa di Sumatera dan Kalimantan S. johorensis umumnya tumbuh pada daerah bergelombang pada ketinggian $<600 \mathrm{~m} \mathrm{dpl}$. 
Dengan diketahuinya beberapa faktor lingkungan tempat tumbuh di sekitar $S$. johorensis seperti besarnya intensitas cahaya matahari yang masuk, $\mathrm{pH}$ tanah dan ketinggian tempat, diharapkan dapat menjadi tambahan informasi dimana dan bagaimana sebaiknya mengembangkan jenis ini di masa mendatang. Pengamatan kondisi lingkungan tempat tumbuh di sekitar S. johorensis pada lokasi-lokasi yang berbeda perlu dilakukan untuk mendapatkan data yang lebih bervariasi sehingga dapat menjadi bahan rujukan teknik silvikultur ini.

\section{KESIMPULAN DAN SARAN}

\section{A. Kesimpulan}

1. Hasil pengamatan terhadap permudaan $S$. johorensis di areal pengamatan PT. HPH Aya Yayang menunjukkan bahwa jumlah permudaan tingkat semai di lokasi tersebut cukup banyak yaitu 2.800 semai/ha, 464 pancang/ha dan 76 tiang/ha. Khusus permudaan tingkat pancang dan tiang, tergolong sangat miskin. Diduga hal ini disebabkan kurang optimalnya kondisi lingkungan bagi pertumbuhan permudaan $S$. johorensis sehingga pertumbuhannya menjadi stagnan dan kemudian mati.

2. Intensitas cahaya yang masuk di sekitar permudaan tingkat semai berkisar antara $22 \%-30 \%$, di sekitar permudaan tingkat pancang 22\%-31\%, di sekitar permudaan tingkat tiang 29\%-36\%. Perbedaan intensitas cahaya yang kecil antara permudaan tingkat semai, pancang dan tiang menunjukkan bahwa penutupan tajuk bagian atas cukup rapat sehingga sedikit sekali sinar matahari yang masuk baik pada lapisan tengah hingga lapisan bawah hutan. Hal ini diduga menjadi penghambat pertumbuhan tegakan, karena stok semai yang berlimpah tidak diimbangi dengan stok permudaan tingkat tiang dan pancang yang miskin di lokasi pengamatan.

3. $\mathrm{pH}$ tanah di lokasi penelitian berkisar antara 4,18-4,2 atau tergolong sangat asam. Pada kondisi demikian permudaan $S$. johorensis masih dapat tumbuh dengan baik.

\section{B. Saran}

Untuk mengetahui pengaruh intensitas cahaya terhadap persentase hidup dan pertumbuhan permudaan alam $S$. johorensis, perlu dilakukan pengamatan lanjutan berkaitan dengan dinamika perkembangan pada hutan bekas tebangan atau hutan alam. Data yang diperoleh sangat berguna dalam menentukan pengembangan $S$. johorensis secara luas terutama untuk menstimulir perkembangan semai jenis tersebut di alam. 


\section{DAFTAR PUSTAKA}

Badan Litbang Kehutanan, 1991. Vademicum Dipterocarpaceae. Terbitan 02/Th I/91, Badan Litbang Departemen Kehutanan. http://www.indonesianforest.com/Dipterocarpaceae/ Silvikultur.PDF

Bratawinata, A.A. 2001. Ekologi Hutan Hujan Tropis dan Metoda Analisis Hutan. Departemen Pendidikan Nasional. Jakarta.

Effendy, M.M. 1987. Respon Pertumbuhan Shorea acuminatissima dan S. leprosula terhadap Cahaya di Hutan Tropika Humida Kalimantan Selatan. Tesis Program Pasca sarjana UGM. Yogyakarta (unpublished).

Hardiyanto, E.B. 2006. Constraint of Forest, Choice of Species. Silviculture Systems of Indonesia's Dipterocarps Forest Management: A lesson learned. In: Rimbawanto (Ed.). Technical Report ITTO Project PD 41/00 Rev. 3 (F,M). Yogyakarta, Indonesia. pp 13-17.

Hardjowigeno, S. 1985. Klasifikasi Tanah, Survey Tanah dan Evaluasi Kemampuan Lahan. Jurusan Tanah, Fakultas Pertanian, IPB. Bogor.

Longman K.A. dan J. Jenik. 1974. Tropical Forest and Its Environtment.Longman Inc., Ney York. USA

Panjaitan, S., R.S. Wahyuningtyas, Supriadi, M. Sulistiani dan Djumani, 2004. Teknik Pengembangan Hutan Tanaman Jenis-jenis Prioritas. Penelitian Teknik Budidaya, Persyaratan Tumbuh dan Sebaran Jenis Shorea johorensis Foxw. Balai Penelitian dan Pengembangan Hutan Tanaman Indonesia Bagian Timur. Banjarbaru. (unpublised).

Purwowidodo, 2000. Mengenal Tanah Hutan. Metode Kaji Tanah. Laboratorium Pengaruh Hutan. Jurusan Manajemen Hutan. Fakultas Kehutanan, IPB. Bogor.

Soerianegara, I dan Indrawan, 1978. Ekologi Hutan Indonesia. Departemen Manajemen Hutan. Fakultas Kehutanan IPB, Bogor.

Sukotjo, 2009.Teknik Silvikultur Intensif (SILIN). Gadjah Mada University Press.

Zulfahani, R.H., 1987. Respon Pertumbuhan Semai Meranti Merah (Shorea johorensis Foxw.) terhadap Intensitas Cahaya di Hutan Pendidikan Mandiangin. Tesis S2 Fakultas Pertanian Program Studi Budidaya Hutan. Universitas Lambung Mangkurat. Banjarbaru. (unpublished).

Wahyuningsih, D.R., 1996. Pengaruh Intensitas Cahaya dan Kandungan Air Tanah terhadap Pertumbuhan, Transpirasi dan Potensial Daun Anakan S. leprosula Miq. Skripsi Fakultas Kehutanan Universitas Mulawarman, Samarinda.(unpublised). 